Chirurgia (2021) 116: 42-50

No. 1, January - February

Copyright@ Celsius

http://dx.doi.org/10.21614/chirurgia.116.1.42

\title{
The Emergency Endoscopic Treatment in Acute Cholangitis
}

\author{
Victor Florescu' ${ }^{1}$, Radu Pârvulețu', Mugur Ardelean', Mihai Angelescu ${ }^{1,2}$, Gabriela Anca Angelescu ${ }^{2,3}$, \\ Octavian Enciu ${ }^{1,2^{*}}$, Niculae lordache ${ }^{2,4}$
}

'Department of Surgery, Elias University Emergency Hospital, Bucharest, Romania

2"Carol Davila" University of Medicine and Pharmacy, Bucharest, Romania

${ }^{3}$ Department of Internal Medicine, Ilfov County Emergency Hospital, Bucharest, Romania

4Department of Surgery, "Sfântul Ioan" Clinical Emergency Hospital, Bucharest, Romania

${ }^{*}$ Corresponding author:

Octavian Enciu, MD

Department of Surgery

Elias University Emergency Hospital

17 Mărăști Blvd, 011461, Bucharest

Romania

E-mail: esoctavian@gmail.com
Received: 22.10.2020

Accepted: 13.01.2021

\section{Rezumat}

Tratamentul endoscopic în urgență pentru colangită acută

Context: Colangita acută este o boală sistemică determinată de inflamația acută şi infecția arborelui biliar şi poate determina rate semnificative de morbiditate şi mortalitate. Cea mai frecventă cauză de colangită este litiaza coledociană, al cărui tratament inadecvat, în formele severe, poate duce la o rată crescută de mortalitate. Actualmente, diagnosticul nu se mai bazează pe triada Charcot, din cauza sensibilitătii scăzute, folosindu-se astfel, ghidurile Tokyo ale căror criterii de diagnostic se bazează pe prezența inflamației sistemice, colestază şi/sau icter şi dovada imagistică a obstrucției biliare. In funcție de severitatea colangitei acute, tratamentul diferă de la antibioterapie până la dezobstrucție biliară endoscopică în regim de urgență. Recomandarea de tratament de primă intenție în cazurile severe este cel endoscopic, realizat prin colangiopancreatografie endoscopică retrogradă (ERCP).

Metodă: Pentru a evalua eficacitatea tratamentului endoscopic prin ERCP în urgență la pacienții cu angiocolită acută, am studiat retrospectiv 185 pacienți ce au suferit intervenții endoscopice în perioada 2018 - septembrie 2020, din care au fost identificați 74 de pacienți cu diferite stadii de colangită acută.

Rezultate: In lotul studiat au fost 42 de femei (56,7\%) şi 32 de bărbați (43,3\%), cu vârsta medie de 62,2 (38-93) ani. Principala cauză de colangită a fost litiaza coledociană obstructivă (44 pacienți, 59,5\%), cu grade diferite de severitate - grad I (41 pacienți, 55,4\%), grad II (22 pacienți, 29,7\%) şi grad III (11 pacienți, 
14,8\%). Pentru cazurile de severitate grad II şi III (33 pacienți, 44,5\%) intervenția endoscopică a avut loc în primele 12-24 ore de la internare. Pacienții la care dezobstrucția endoscopică a fost efectuată în primele 12-24 de ore au avut analize normale în medie la 4,7 zile de la internare şi durata medie de internare de 5,8 zile pe când pacienții cu dezobstructie efectuată după 24 de ore au avut analize normale la 6,3 zile iar internarea a durat în medie 7,6 zile. Au fost înregistrate 4 decese $(5,4 \%)$, toate în grupul de severitate grad III.

Concluzie:Pacienții care au beneficiat de dezobstrucție biliară endoscopică în primele 24 ore de la internare au avut o recuperare postintervențională mai rapidă, antibioterapie de scurtă durată, spitalizare redusă, morbidiate şi mortalitate mai scăzute față de cei la care intervenția endoscopică a avut loc după 24 de ore.

Cuvinte cheie: colangita acută, colangiopancreatografie endoscopică retrogradă, litiaza coledociană

\begin{abstract}
Background:Acute cholangitis is a systemic disease caused by acute inflammation and infection of the biliary tree and carries significant morbidity and mortality rates. The most common cause of acute cholangitis is choledocholithiasis, which can lead to an increased death rate in severe forms and in the absence of appropriate treatment. The clinical Charcot's triad is outdated due to low sensitivity and has been replaced with the criteria established by the Tokyo guidelines. The criteria of diagnosis are based on the presence of systemic inflammation, cholestasis and/or jaundice and biliary obstruction documented by imaging studies. Depending on the severity of the disease, treatment varies from antibiotic therapy to emergency endoscopic biliary drainage. In severe cases the first-line treatment is achieved by endoscopic retrograde cholangiopancreatography (ERCP).

Method:To evaluate the effectiveness of urgent ERCP treatment in patients with acute cholangitis, a retrospective data analysis was performed of 185 patients that underwent endoscopic interventions between 2018 and September 2020, 74 patients of which have been identified with different grades of acute cholangitis.

Results: The studied group consisted of 42 women (56.7\%) and 32 men (43.3\%), with a mean age of 62.2 (38-93) years. Obstructive choledocholithiasis was as the main cause of cholangitis (44 patients, $59.5 \%$ ), with varying degrees of severity - grade I (41, 55.4\%), grade II (22 patients, $29.7 \%$ ) and grade III (11 patients, 14.8\%). For cases with grade II and III of severity (33 patients, $44.5 \%$ ), the endoscopic intervention took place in the first $12-24$ hours after admission. Patients that had endoscopic dezobstruction in the first 12-24 hours had normal blood tests in 4.7 days (mean) and 5.8 days (mean) of hospital stay while patients that had dezobstruction more than 24 hours after admission had normal blood tests in 6.3 days (mean) and 7.6 days of hospital stay. Mortality was $5.4 \%$, all 4 patients having grade III severity cholangitis.

Conclusion: Patients that benefited from endoscopic biliary drainage in the first 24 hours after admission had a faster recovery, decreased duration of antibiotic therapy, decreased duration of hospital stay, lower morbidity and mortality rate compared to those that suffered the intervention more than 24 hours after admission.
\end{abstract}

Key words: acute cholangitis, endoscopic retrograde cholangiopancreatography, choledocholithiasis

Introduction

Acute cholangitis is an inflammatory condition of the biliary tract that can evolve into a severe disease accompanied by organ dysfunction, caused by systemic inflammatory response 
syndrome (SIRS) and/or sepsis with or without multiple systems organ failure (1). Choledocholithiasis is the most common cause of acute cholangitis, although, recently, the number of cases caused by obstructive benign or malignant conditions (10-30\%), sclerosing cholangitis, endoscopic maneuvers on the biliary tract (with biliary stent obstruction), reflux disease after sphincterotomy, have been increasing (2). The incidence of gallstones in the general population is $10 \%$, of which $1-2 \%$ are asymptomatic and $1-3 \%$ of symptomatic patients annually present with severe symptoms or complications (pancreatitis, colangitis, acute cholecystitis, jaundice)(3). The mortality rate for acute cholangitis was over $50 \%$ before the $1980 \mathrm{~s}, 10-30 \%$ before the 1990 s and $2-10 \%$ after the 2000 s but with a rate of $12.3 \%$ for severe cases. (4) The mechanism that causes acute cholangitis is biliary obstruction that determines an increase in bile duct pressure from the normal pressure of 7 to $14 \mathrm{~cm} \mathrm{H} 2 \mathrm{O}$ to $20-30 \mathrm{~cm} \mathrm{H} 2 \mathrm{O}$. This leads to a biliary-venous and lymphatic reflux caused by the absence of a basal membrane between sinusoids and bile ducts allowing the passage of bacteria in the systemic circulation and, therefore, leading to septic shock.(5) The diagnosis was historically based on the clinical Charcot's triad (abdominal pain, fever and jaundice), but its lack of sensitivity has led to the introduction of the Tokyo Guidelines in 2007 (TG07), with updated versions in 2013 (TG13) and 2018 (TG18), which include biological and imaging data. $(6,7)$ Treatment varies depending on severity according to TG13 / TG18. Thus, in mild cases, treatment is based on antibiotherapy, without the need for biliary drainage. However, in patients who do not respond to initial treatment, endoscopic drainage should be considered. In patients with moderate cholangitis, early endoscopic intervention associated with antibiotic treatment is indicated. In patients with severe cholangitis, with organ failure induced by sepsis, ventilatory and circulatory support is required along with emergency endoscopic interventions and antibiotic therapy. The etiological treatment, if necessary, will be introduced as soon as the patient's condition improves $(8,9)$. In a study of 90 patients, Khashab et al. showed that unsuccessful or delayed endoscopic intervention (endoscopic retrograde cholangiopacreatography) predicts prolonged hospital stay and increased costs of hospitalization (10). Moreover, delayed ERCP is associated with persistent organ failure, admission to the intensive care unit and death. Patients with a high ASA score and delayed ERCP suffer the worst outcome and prolonged hospitalization $(11,12)$. The aim of this analysis is to show the efficacy of emergency endoscopic retrograde cholangiopancreatography (ERCP) in the treatment of acute cholangitis, depending on its severity, and the possible benefits to the patient in terms of morbidity and mortality.

\section{Material and Method}

A retrospective analysis was performed of the data from 185 patients admitted at Elias Emergency University Hospital, General Surgery Department, who underwent endoscopic interventions between January 2018 and September 2020. Seventy-four patients who had associated biliary tract infection according to the Tokyo 2018 Guidelines (Table 1) were selected from the lot. The severity of the cholangitis was identified using the Tokyo 2018 criteria. All of the selected patients benefited from successful endoscopic maneuvers. The therapeutic endoscopy team consisted of 3 surgeons, 2 with extensive endoscopic experience $(>10$ years) and one surgeon with less experience (3 years) in such maneuvers. We analyzed the progress of the periprocedural physiological parameters, the timing of biliary decompression, the complication rates, the length of hospital stay, the morbidity and mortality.

\section{Results}

Out of 74 patients, $57 \%$ were female, with median age of 62.2 , the majority of the patients being in their sixth decade, with extreme ages of 16 and 101 . The main causes 
Table 1. Causes of obstruction and procedures performed

\begin{tabular}{cllc}
\hline Patients (No) & Cause of Obstruction & Procedure & Procedures (No) \\
\hline 44 & Choledocholithiasis & Sphincterotomy + stone extraction & 39 \\
& & Sphincterotomy + stent placement & 5 \\
\hline 20 & Pancreatic/Biliary Tree Cancer & Stent placement & 20 \\
\hline 4 & Biliary Stent Obstruction & Stent replacement & 4 \\
\hline 3 & $\begin{array}{l}\text { Papilitis and stenosis of the sphincter } \\
\text { of Oddi }\end{array}$ & Sphincterotomy + lavage & 3 \\
\hline 3 & Benign Stenosis of Common Bile Duct & Sphincterotomy + pneumatic dilation & 3 \\
& & Stent placement & 2 \\
\hline
\end{tabular}

of cholangitis were represented by obstructive lithiasis (44 cases) (Fig. 1), 20 cases of obstructive pancreatic or biliary tree neoplasms, 4 cases of cholangitis associated with biliary stent obstruction, 3 patients with papillitis and stenosis of the sphincter of Oddi and 3 patients with benign stenosis of the common bile duct (Table 1). The diagnosis was based on Tokyo 2018 Guidelines Criteria (TG18), obstructive cholangitis being confirmed by the presence of a criteria from categories A, B and C. According to TG18 and depending of severity, patients were classified as grade I (41 patients, $55.4 \%$ ), grade II (22 patients, $29.7 \%$ ), grade III (11 patients, 14.8\%) (Table 2). All patients classified as grade III went through the endoscopic procedure in the first 12 hours after admission, while those with grade II severity had endoscopic treatment in the first 24-48 hours after admission. The endoscopic techniques used for choledocholithiasis were

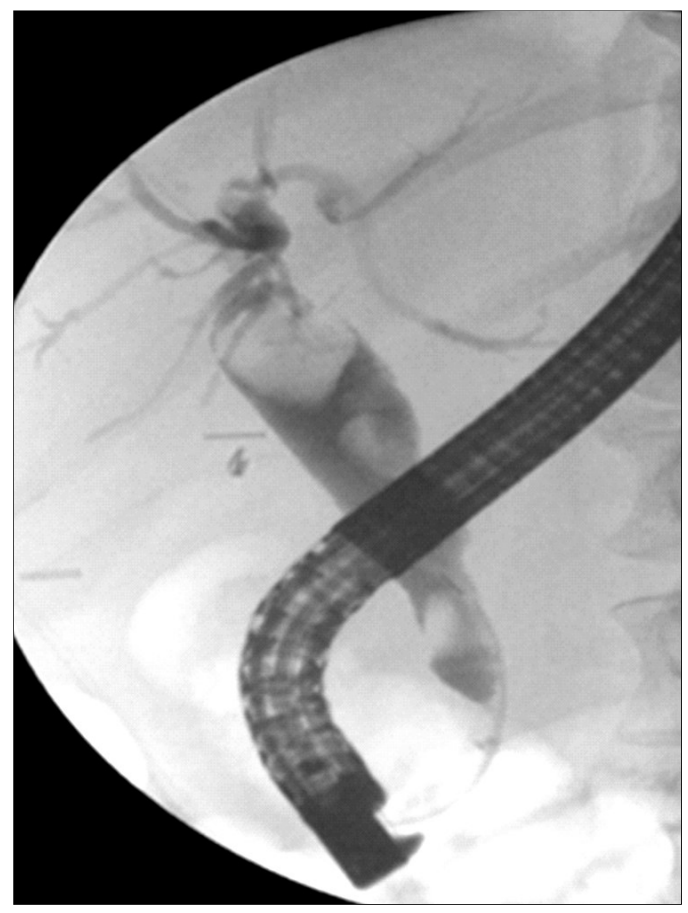

Figure 1. Biliary tree lithiasis

Table 2. Severity grading according to TG18 criteria

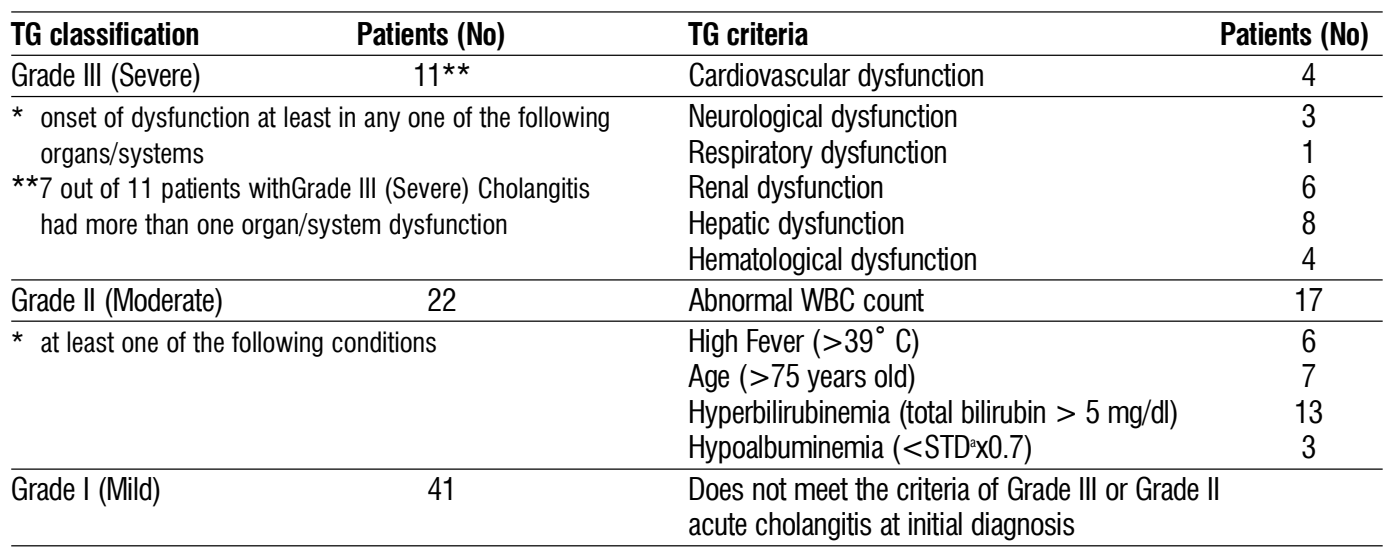




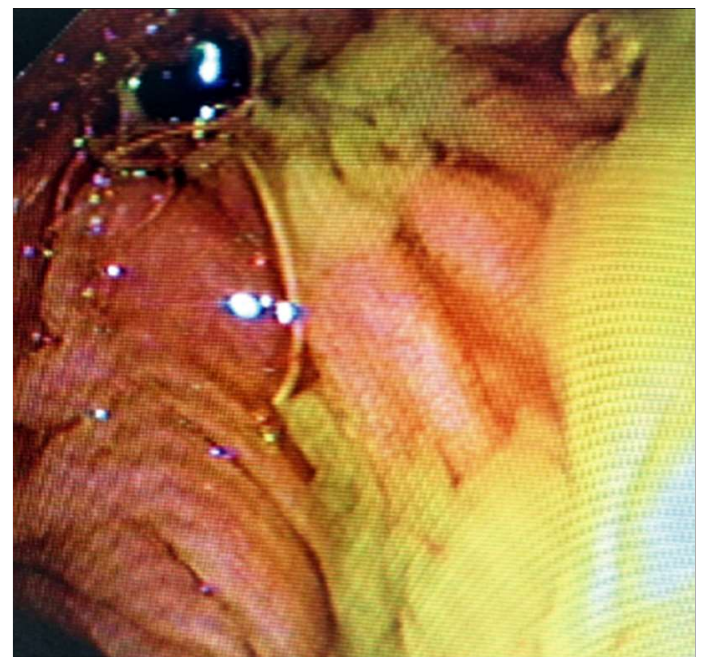

Figure 2. Acute cholangitis - impacted stone in the duodenal papilla

as following: 39 sphincterotomies with stone extraction and lavage of the common bile duct (Fig. 2) and 5 sphincterotomies with plastic stent placement for large lithiasis $(>2 \mathrm{~cm})$ which were subsequently resolved endoscopically by lithotripsy when the patient's condition permitted. For obstructive pancreatic or biliary tract neoplasm plastic stent were placed for biliary drainage (Fig. 3). For acute cholangitis associated with biliary stent obstruction replacement of the stent was performed. Patients with papillitis and stenosis of the Oddi sphincter required endoscopic sphincterotomy and common bile duct lavage. For those with benign stenosis of the common bile duct, sphincterotomy with pneumatic dilatation of the biliary tract and plastic stent placement were performed in 2 of the 3 patients (Fig. $D$.

Regarding physiological parameters, we have noticed only a slight improvement in liver function in a nonsignificant number of patients with grade II cholangitis, but inflammation markers remained elevated in all patients who have received 24 hours of conservative treatment before ERCP. The initial empirical antibiotic regimen was an association of Ciprofloxacin and Metronidazole or Meropenem and was adjusted by case after obtaining the result of the antibiogram.

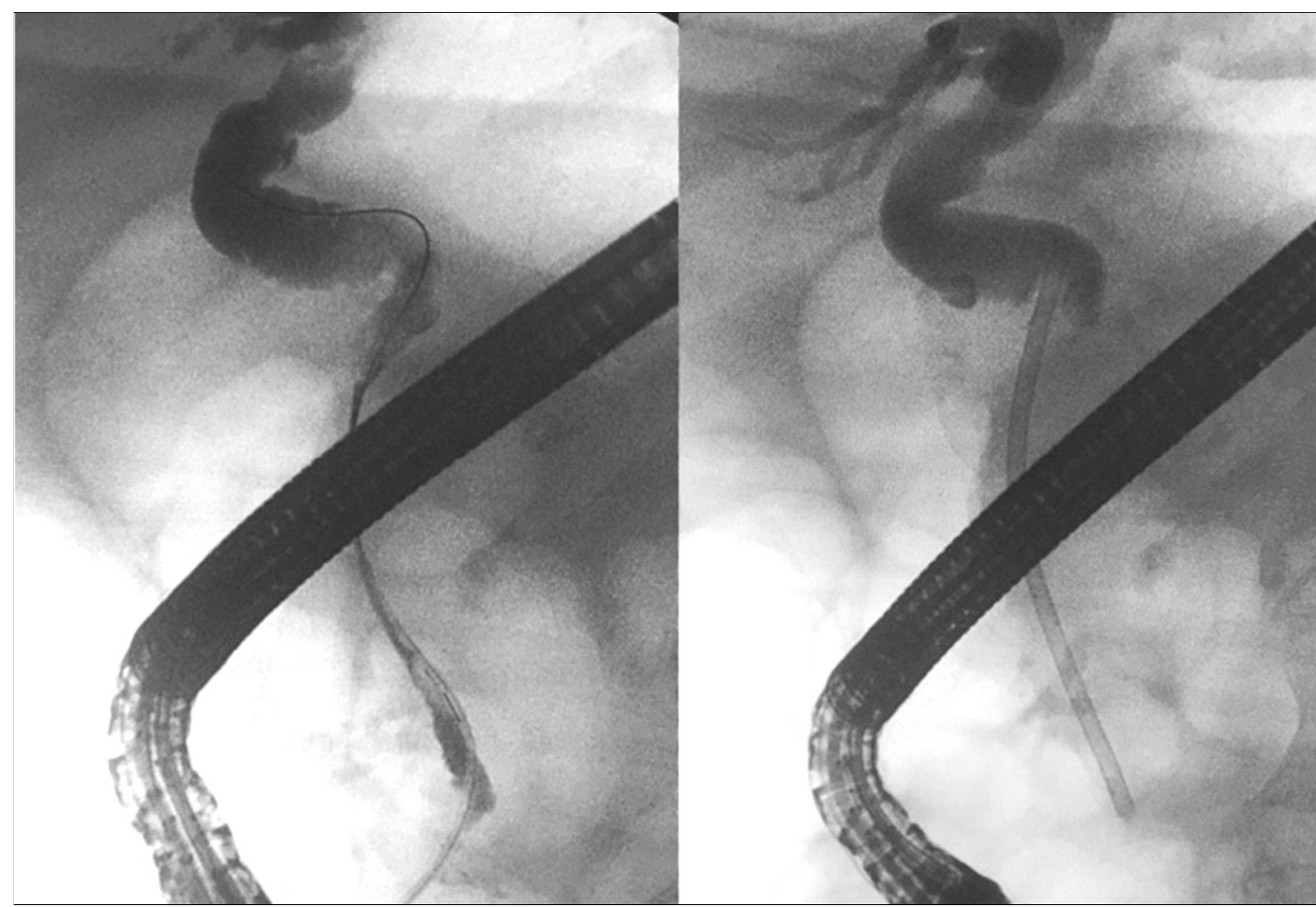

Figure 3. Pancreatic tumor 


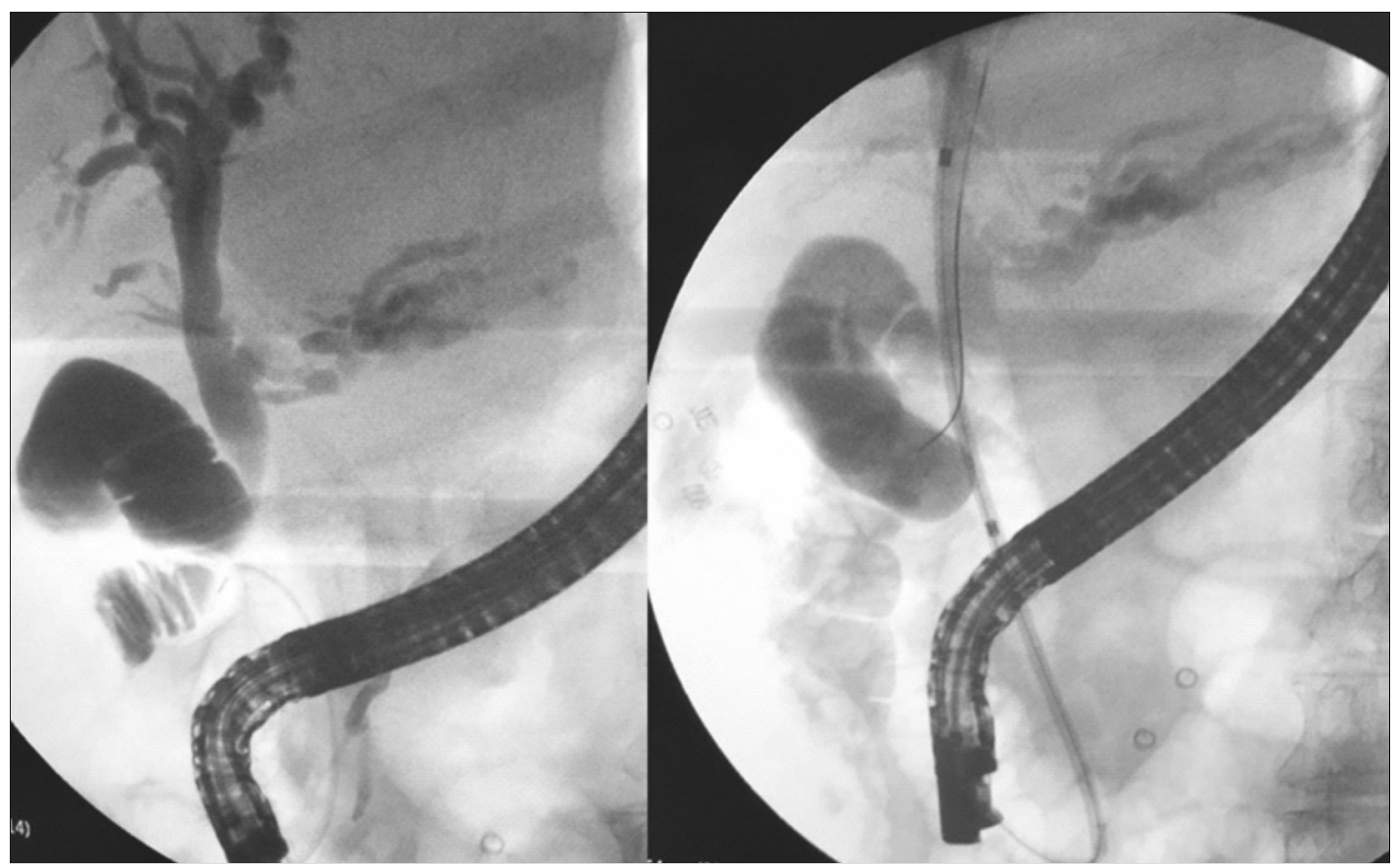

Figure 4. Obstructive biliodigestive anastomosis

Regardless of the timing of endoscopic desobstruction, antibiotics were administered until normal blood test were obtained.

Patients that benefited from endoscopic desobstruction in the first 24 hours from admission had normal physiological parameters in 4.7 days, while those who had endoscopic intervention after 24 hours took 6.3 days to achieve these results. Patients with early desobstruction had an average hospital stay of 5.8 days compared to 7.6 days for those whose intervention took place after 24 hours.

The main post-ERCP complications were: acute post-procedural pancreatitis $(6.75 \%-5$ out of 74 patients) that resolved with conservative treatment (electrolytic balancing, intrarectal NSAID, pain medication) but prolonged hospitalization by 3.48 days; upper digestive hemorrhage due to papillary bleeding $(5.40 \%$ - 4 out of 74 patients) that occurred at 24-72 hours, especially in patients with altered coagulation tests and was resolved endoscopically by injection or clipping. Mortality was 5.4\% (4 patients), all patients with grade III cholangitis and it was not a consequence of the endoscopic procedure but rather due to uncontrollable sepsis and/or severe comorbidities (2 patients died of coronary events, 1 of uncontrollable sepsis and one of respiratory complications requiring ventilation).

\section{Discussion}

The management of patients with different degrees of acute biliary tract infection is critical, because subsequent evolution is greatly influenced by the timing of the intervention (13). The decision to intervene endoscopically should be made only after establishing the degree of severity according to the TG18 criteria (ESGE recommendation). Since 2007, following the Tokyo consensus, experts have agreed on the timing of the endoscopic procedure; therefore, in severe cholangitis it should be as soon as possible, while in mild cases following conservative treatment (14). Regarding moderate cholangitis, Japanese experts prefer the endoscopic approach in the first 12 hours while others prefer it take place following conservative treatment. The ESGE 
Guideline suggests immediate intervention or in the first 12 hours in patients with severe cholangitis and signs of shock, in 24-72 hours in patients with moderate cholangitis and electively in those with mild cholangitis. Most patients with biliary tract lithiasis develop mild to moderate cholangitis and respond well to first-line antibiotic therapy. However, between $15-30 \%$ of patients develop severe cholangitis and require urgent biliary drainage (14). When acute cholangitis and acute cholecystitis are associated, the therapeutic strategy will be adapted according to the patient's condition, but when laparoscopic cholecystectomy and ERCP are opted for, laparoscopic ultrasound or selective intraoperative cholangiography will be performed when it is technically possible $(15,16)$. If during surgery severe lesions are found such as acute scleroatrophic cholecystitis with biliary-biliary fistula, migration in the common bile duct and acute cholangitis, the endoscopic intervention might be the only indicated therapeutic procedure (17).

Endoscopic transpapillary biliary drainage should be taken into consideration as the first drainage method due to its low invasiveness, less pain and a lower risk of adverse events, despite the risk of acute post-ERCP pancreatitis (18-20). Transpapillary drainage can be achieved by stent placement or by nasobiliary drainage. There is no statistical evidence in terms of success rate and effectiveness between the two maneuvers (21). The advantage of internal drainage is related to the patient's comfort, especially in elderly patients who can accidentally suppress their nasobiliary drainage.

In our Department, during the studied period, no nasobiliary drains were used. Endoscopic sphincterotomy in patients with acute cholangitis caused by lithiasis allows definitive treatment or placement of a drainage stent. The ESGE TG18 recommendation is that sphincterotomy and treatment of choledochal lithiasis be performed in patients with mild and moderate cholangitis (recommendation level 2, grade $\mathrm{C}$ ). It is known that in severe cholangitis, the risk of bleeding after sphincterotomy is much higher, even in the absence of coagulation disorders. If the definitive treatment of choledochal lithiasis is not attempted, the placement of a stent $(10 \mathrm{Fr})$ is preferable to be performed without sphincterotomy (22). In elderly patients with multiple comorbidities and severe cholangitis, stenting is preferred as primary intention, compared to sphincterotomy and definitive treatment of lithiasis. In these cases, stenting is linked to significantly fewer short-term complications. Elective treatment can be performed after the patient's condition improves (23). The ESGE TG18 recommendation is to not associate sphincterotomy with stent placement in patients with acute cholangitis (recommendation level 2, grade A) or in those with antithrombotic treatment (recommendation level 1, grade D).

Early endoscopic biliary drainage has led to a low mortality rate in elderly patients, who are affected by multiple comorbidities and who can easily reach organ failure in the event of septic shock. The rate of failure of treatment and mortality rate can be assessed, as early as presentation, using the SPIAS Severity Score (24). Salek et al. studied predictive factors for increased mortality and the need for early ERCP in patients with acute cholangitis (25). They identified that total bilirubin, partial thromboplastin time and the presence of liver abscesses are predictive of increased mortality. Alanine aminotransferase and leukocytosis are predictive factors for the need for immediate ERCP (25). In a published study that included patients with acute cholangitis, 3 out of 6 patients $(50 \%)$ with failed biliary drainage died, compared to 2 out of 321 patients $(0.6 \%)$ with successful biliary drainage (26). In our retrospective analysis, we found a significant improvement in inflammatory markers, transaminases, alkaline phosphatase and bilirubin levels after performing ERCP in patients with acute cholangitis. Hospital stay was shorter for those whose endoscopic intervention was performed in the first 24 hours. The major complications after ERCP in our department upper digestive bleeding and pancreatitis resolved with conservative treatment and/or 
endoscopic management and did not require surgery. The rate of post-procedural pancreatitis was $6.75 \%$, well within the boundaries of published studies, and none was severe to require surgery and its burden $(27,28)$. Four patients with grade III cholangitis died. These fatalities could not be attributed the endoscopic procedure or biliary sepsis but rather to their severe pulmonary and cardiac comorbidities. As Table 2 shows, most of the 11 patients in the grade III severity group had onset of dysfunction in more than one organ/system required as criteria for diagnosis of severity. The youngest of the 11 patients was 78 , the oldest 87 , and yet age above 75 is required only for diagnosis of moderate cholangitis but one can envisage that advanced age can only be a poor prognosis factor for severe cholangitis.

\section{Conclusions}

Emergency endoscopic management (under 24 hours) for acute cholangitis, especially in severe forms, is associated with shorter hospital stay, decreased mortality and morbidity. The endoscopic drainage technique must be adapted taking into consideration the severity of cholangitis, the cause that led to cholangitis, the patient's condition as well as comorbidities and associated medical treatments.

\section{Conflict of Interest Statement}

The authors declare no conflicts of interest.

\section{References}

1. Wada K, Takada T, Kawarada Y, Nimura Y, Miura F, Yoshida M, et al. Diagnostic criteria and severity assessment of acute cholangitis: Tokyo Guidelines. J Hepatobiliary Pancreat Surg. 2007;14(1):52-8.

2. Lee JG. Diagnosis and management of acute cholangitis. Nat Rev Gastroenterol Hepatol. 2009;6(9):533-41.

3. Friedman GD. Natural history of asymptomatic and symptomatic gallstones. Am J Surg. 1993;165(4):399-404.

4. Kiriyama S, Kumada T, Tanikawa M, Hisanaga $Y$, Toyota $H$, Kanamori A. Verification of the current JPN guidelines for the management of acute cholangitis and cholecystitis: diagnostic criteria and severity assesment. J Abdom Emerg Med. 2011; 31:475-82.

5. Tringali A. Endoscopic Management of Common Bile Duct Stones. J Gastroenterol Hepatol Res. 2016;5(6):2212-27.
6. Kiriyama S, Takada T, Strasberg SM, Solomkin JS, Mayumi T, Pitt $\mathrm{HA}$, et al. TG13 guidelines for diagnosis and severity grading of acute cholangitis (with videos). J Hepatobiliary Pancreat Sci. 2013;20(1):24-34.

7. Kiriyama S, Kozaka K, Takada T, Strasberg SM, Pitt HA, Gabata T, et al. Tokyo Guidelines 2018: diagnostic criteria and severity grading of acute cholangitis (with videos). J Hepatobiliary Pancreat Sci. 2018;25(1):17-30.

8. Yokoe M, Hata J, Takada T, Strasberg SM, Asbun HJ, Wakabayashi G, et al. Tokyo Guidelines 2018: diagnostic criteria and severity grading of acute cholecystitis (with videos). J Hepatobiliary Pancreat Sci. 2018;25(1):41-54.

9. Miura F, Takada T, Strasberg SM, Solomkin JS, Pitt HA, Gouma DJ, et al. TG13 flowchart for the management of acute cholangitis and cholecystitis. J Hepatobiliary Pancreat Sci. 2013;20(1):47-54.

10. Khashab MA, Tariq A, Tariq U, Kim K, Ponor L, Lennon AM, et al. Delayed and Unsuccessful Endoscopic Retrograde Cholangiopancreatography Are Associated With Worse Outcomes in Patients With Acute Cholangitis. Clin Gastroenterol Hepatol. 2012;10(10): 1157-61.

11. Navaneethan U. Factors predicting adverse short-term outcomes in patients with acute cholangitis undergoing ERCP: A single center experience. World J Gastrointest Endosc. 2014;6(3):74.

12. Lee F, Ohanian E, Rheem J, Laine L, Che K, Kim JJ. Delayed endoscopic retrograde cholangiopancreatography is associated with persistent organ failure in hospitalised patients with acute cholangitis. Aliment Pharmacol Ther. 2015;42(2):212-20.

13. Sekimoto M, Takada T, Kawarada Y, Nimura Y, Yoshida M, Mayumi T, et al. Need for criteria for the diagnosis and severity assessment of acute cholangitis and cholecystitis: Tokyo Guidelines. J Hepatobiliary Pancreat Surg. 2007;14(1):11-4.

14. Nagino M, Takada $T$, Kawarada $Y$, Nimura $Y$, Yamashita $Y$, Tsuyuguchi T, et al. Methods and timing of biliary drainage for acute cholangitis: Tokyo Guidelines. J Hepatobiliary Pancreat Surg. 2007;14(1):68-77.

15. Cociorvei A, Calu V. Laparoscopic ultrasound in billiary diseases. Chirurgia (Bucur). 2011;108(3):353-8.

16. Giulea C, Enciu 0, Bîrca T, Miron A. Selective intraoperative cholangiography in laparoscopic cholecystectomy. Chirurgia (Bucur). 2016;111(1):26-32.

17. Calu V, Dumitrescu I, Miron A. The role of laparoscopy in the surgical treatment of scleroatrophic cholecystitis. Chirurgia (Bucur). 2010;105(5):653-6. Romanian

18. Lai EC, Mok FP, Tan ES, Kaplan MM. Endoscopic biliary drainage for severe acute cholangitis. Ann Intern Med. 1992;117(Suppl. 3):70.

19. Boender J, Nix GAJJ, De Ridder MAJ, Dees J, Schutte HE, Van Buuren HR, et al. Endoscopic sphincterotomy and biliary drainage in patients with cholangitis due to common bile duct stones. Am J Gastroenterol. 1995;90(2):233-8.

20. Lau JYW, Ip SM, Chung SCS, Leung JWC, Ling TKW, Yung MY, et al. Endoscopic drainage aborts endotoxaemia in acute cholangitis. Br J Surg. 1996;83(2):181-4.

21. Otani $\mathrm{K}$, Ueki T, Matsumura K, Maruo T, Minoda R, Otsuka $Y$, et al. Comparison Between Endoscopic Biliary Stenting and Nasobiliary Drainage in Patients with Acute Cholangitis due to Choledocholithiasis: Is Endoscopic Biliary Stenting Useful? Hepatogastroenterology. 2015;62(139):558-63.

22. Freeman ML, Nelson DB, Sherman S, Haber GB, Herman ME, Dorsher PJ, et al. Complications of Endoscopic Biliary Sphincterotomy. N Engl J Med. 1996;335(13):909-19.

23. Ramchandani M, Pal P, Reddy DN. Endoscopic management of acute cholangitis as a result of common bile duct stones. Dig Endosc. 2017;29:78-87.

24. Sartelli M, Abu-Zidan FM, Labricciosa FM, Kluger Y, Coccolini F, Ansaloni L, et al. Physiological parameters for Prognosis in Abdominal Sepsis (PIPAS) Study: A WSES observational study. 
World J Emerg Surg [Internet]. 2019;14(1):34. Available from: https://doi.org/10.1186/s13017-019-0253-2

25. Salek J, Livote E, Sideridis K, Bank S. Analysis of risk factors predictive of early mortality and urgent ERCP in acute cholangitis. J Clin Gastroenterol. 2009;43(2):171-5.

26. Park CS, Jeong HS, Kim KB, Han JH, Chae HB, Youn SJ, et al Urgent ERCP for acute cholangitis reduces mortality and hospital stay in elderly and very elderly patients. Hepatobiliary Pancreat Dis
Int. 2016;15(6):619-25.

27. Dumonceau J-M, Andriulli A, Devière J, Mariani A, Rigaux J, Baron TH, et al. European Society of Gastrointestinal Endoscopy (ESGE) Guideline: prophylaxis of post-ERCP pancreatitis. Endoscopy. 2010;42(06):503-15.

28. Calu V, Dutu M, Parvuletu R, Miron A. Persistent pancreatic fistula after surgical necrosectomy for severe pancreatitis. Chirurgia (Bucur). 2012;107(6):796-801. 